\title{
Chlorophyll and nitrate meters as nitrogen monitoring tools for selected vegetables in Southern Ontario
}

Westerveld, S.M., McKeown, A.W., McDonald, M.R. and Scott-Dupree, C.D.

This is the peer reviewed version of the article, which has been published in final form at https://doi.org/10.17660/ActaHortic.2003.627.33 International Society for Horticultural Science.

Suggested Citation: Westerveld, S.M., McKeown, A.W., McDonald, M.R. and ScottDupree, C.D. (2003). Chlorophyll and nitrate meters as nitrogen monitoring tools for selected vegetables in Southern Ontario. Acta Hortic. 627, 259-266. DOI:

10.17660/ActaHortic.2003.627.33 


\section{Chlorophyll and nitrate meters as nitrogen monitoring tools for selected vegetables in Southern Ontario}

\section{Westerveld, S.M. ${ }^{1}$, McKeown, A.W. ${ }^{1}$, McDonald, M.R. ${ }^{1}$ and Scott-Dupree, C.D. ${ }^{2}$}

Affiliation: ${ }^{1}$ Department of Plant Agriculture, University of Guelph, Guelph, Ontario, Canada N1G 2W1; '2Department of Environmental Biology, University of Guelph, Guelph, Ontario, Canada N1G 2W1

Abstract: With the introduction of nutrient management legislation in the province of Ontario there is a need to evaluate methods to improve the nitrogen $(N)$ use efficiency of vegetable production. The effectiveness of the Horiba 'Cardy' Model C-141 nitrate $\left(\mathrm{NO}_{3}{ }^{-}\right)$meter and Minolta SPAD-502 chlorophyll meter for determining $\mathrm{N}$ status were evaluated and compared to traditional laboratory $\mathrm{N}$ analysis in onions, carrots, and cabbage grown on both organic soil in the Holland/Bradford Marsh, Ontario and mineral soil near Simcoe, Ontario in 2000 and 2001. Nitrogen was applied at 0, 50, 100, 150, and $200 \%$ (cabbage and carrots) and 0,100 , and $200 \%$ (onions) of the rates recommended by the Ontario Ministry of Agriculture, Food, and Rural Affairs for each crop and soil type. At three times during the growing season, $\mathrm{NO}_{3}-\mathrm{N}$ levels in sap from recently mature plant material and in soil were assessed using a Cardy $\mathrm{NO}_{3}-$ meter, chlorophyll readings were taken from mature leaves with the SPAD meter, and soil and tissue samples were collected and submitted for laboratory $\mathrm{N}$ and $\mathrm{NO}_{3}-\mathrm{N}$ analysis. Soil $\mathrm{NO}_{3}-\mathrm{N}$ readings from the Cardy $\mathrm{NO}_{3}-$ meter were highly correlated with laboratory soil $\mathrm{NO}_{3}-\mathrm{N}$ results for all mineral soil plots in both years and on organic soil when suitable procedures were developed in 2001 . Cardy sap $\mathrm{NO}_{3}-\mathrm{N}$ readings were correlated with laboratory $\mathrm{NO}_{3}-\mathrm{N}$ results in the majority of sampling dates for the three crops. SPAD chlorophyll meter readings correlated less with laboratory results, except for cabbage in 2001 when readings were highly correlated with laboratory results. The Cardy $\mathrm{NO}_{3}{ }^{-}$ meter can be used to monitor the $\mathrm{N}$ status of onions, carrots, and cabbage. The SPAD 
chlorophyll meter could be suitable for cabbage $\mathrm{N}$ monitoring but had limited usefulness for $\mathrm{N}$ monitoring of onions and carrots under these conditions.

Keywords: cabbage, carrots, onions, SPAD, Cardy, nutrient management

\section{Introduction}

Nutrient management legislation has been introduced in Ontario that may force vegetable growers to restrict nitrogen $(\mathrm{N})$ application and improve $\mathrm{N}$ use efficiency. Infield nitrate $\left(\mathrm{NO}_{3}{ }^{-}\right)$and chlorophyll meters have been developed that may rapidly and accurately monitor $\mathrm{N}$ concentrations of both soil and tissue and allow for improved $\mathrm{N}$ management of these crops.

The Horiba 'Cardy' $\mathrm{NO}_{3}{ }^{-}$meter (Horiba Co., Japan) can be used directly in the field for both sap and soil analysis. As with laboratory tissue analysis, $\mathrm{NO}_{3}{ }^{-}$standards for every crop and growth phase must be established for proper use of in-field $\mathrm{NO}_{3}-$ meters (Gardner and Roth, 1989). The Cardy $\mathrm{NO}_{3}-$ meter has been used successfully for sap analysis in wheat, rye (Delgado and Follett, 1998), celery, lettuce, pepper, tomato (Hartz et al., 1993), potato (Westcott et al., 1993), and carrot (Warncke, 1996). Although the meter has not been extensively tested on onions or cabbage, meter readings were correlated with dry matter $\mathrm{NO}_{3}{ }^{-}$determinations in other cole crops (Hartz et al., 1993; Kubota et al., 1996; Kubota et al., 1997). Cardy meter soil $\mathrm{NO}_{3}{ }^{-}$readings on mineral soil have been correlated with conventional laboratory techniques in many vegetable crops (Hartz et al., 1993).

The Minolta SPAD-502 chlorophyll meter (Soil-Plant-Analysis-Development section of Minolta Camera Co., Ramsey, NJ) can be used for a rapid determination of the chlorophyll content of individual leaves. SPAD chlorophyll meter readings have been correlated with tissue total N concentrations in corn (Dwyer et al., 1991; Wood et al., 1992; Piekielek and Fox, 1992; Blackmer and Schepers, 1994), wheat (Follett et al., 1992; Reeves et al., 1993), and rice (Turner and Jund, 1991). No reports were found on the use of the SPAD chlorophyll meter on these vegetable crops.

The benefit of chlorophyll meters is they can be used to identify deficiencies without the establishment of critical levels for every crop. Field chlorophyll readings can be 
compared to an in-field reference plot that has been adequately fertilized (Blackmer and Schepers, 1995), because chlorophyll levels reach a plateau in adequately fertilized crops (Schepers et al., 1992).

The objectives of this study were: 1) to evaluate the potential of the SPAD chlorophyll and Cardy $\mathrm{NO}_{3}{ }^{-}$meters for $\mathrm{N}$ monitoring and management tools in cabbage, onions, and carrots through a comparison of meter readings to laboratory analysis, and 2) to evaluate the effect of plant structure on meter use.

\section{Materials and methods}

Nitrogen rate studies were conducted in 2000 and 2001 on cabbage (Brassica oleracea var. capitata L.), onions (Allium cepa L.), and carrots (Daucus carota L.) grown on organic soil, at the University of Guelph - Muck Crops Research Station $\left(44^{\circ} 15^{\prime} \mathrm{N} 77^{\circ}\right.$ $90 ' \mathrm{~W})$, Holland/Bradford Marsh, Ontario and on mineral soil, a grey brown luvisol, at the University of Guelph, Simcoe Campus ( $\left.42^{\circ} 51^{\prime} \mathrm{N} 80^{\circ} 16^{\prime} \mathrm{W}\right)$, Simcoe, Ontario. Total May to September rainfall was 610 and $325 \mathrm{~mm}$ in Simcoe and 575 and $293 \mathrm{~mm}$ for the Holland/Bradford Marsh in 2000 and 2001, respectively (normal for both sites $=400$ $\mathrm{mm}$ ). In 2001, supplemental irrigation was applied at Simcoe in the amount of $113 \mathrm{~mm}$ for cabbage, $75 \mathrm{~mm}$ for onions, and $138 \mathrm{~mm}$ for carrots, and at the Holland/Bradford Marsh in the amount of $50 \mathrm{~mm}$ for carrots.

Carrots and onions were grown on organic soil in 2000 and 2001. 'Hamlet' onions were direct seeded ( 36 seeds $/ \mathrm{m}$ ) into the field with $40 \mathrm{~cm}$ row spacing. 'Idaho' carrots were direct seeded $(80$ seeds $/ \mathrm{m}$ ) into the field in hills $20 \mathrm{~cm}$ high and $86 \mathrm{~cm}$ apart. Plots were arranged in a split plot design with $\mathrm{N}$ rate as the main plot and cultivar as the subplot with four replications.

Cabbage, carrots, and onions were grown on mineral soil in 2000 and 2001. 'Atlantis' cabbage was seeded in plastic plug trays, and transplanted into the field with row spacing of $75 \mathrm{~cm}$ and within row spacing of $45 \mathrm{~cm}$. 'Winner' onions were direct seeded $(10$ seeds $/ m)(2000)$ and seeded in plastic plug trays and transplanted (2001) into the field with row spacing of $75 \mathrm{~cm}$ and within row spacing of $15 \mathrm{~cm}$. 'Annapolis' (2000) and 'Idaho' (2001) carrots were direct seeded (80 seeds $/ \mathrm{m}$ ) into the field with row spacing of 
$35 \mathrm{~cm}$. Plots were arranged in a randomized complete block design with four replications. Total yield of cabbage, onions, and carrots was assessed at maturity.

Nitrogen was applied at $0,50,100,150$, and $200 \%$ of the Ontario Ministry of Agriculture, Food, and Rural Affairs' recommendations on carrots $(60 \mathrm{~kg} / \mathrm{ha} \mathrm{N}$ all preplant on organic soil; $110 \mathrm{~kg} / \mathrm{ha} \mathrm{N}$ split $66 \%$ preplant/ $33 \%$ sidedress on mineral soil) and cabbage (128 kg/ha preplant and $42 \mathrm{~kg} / \mathrm{ha}$ sidedress on mineral soil, OMAFRA, 2000). Nitrogen was applied at 0,100 and $200 \%$ of the recommended rate for onions $(90 \mathrm{~kg} / \mathrm{ha}$ $\mathrm{N}$ preplant on organic soil; $120 \mathrm{~kg} / \mathrm{ha}$ split $66 \%$ preplant $/ 33 \%$ sidedress on mineral soil, OMAFRA, 2000). In all plots $\mathrm{N}$ was applied as calcium ammonium nitrate preplant and potassium nitrate for sidedress applications.

At three times during the growing season (two for carrots on organic soil in 2000), the $\mathrm{NO}_{3}{ }^{-} \mathrm{N}$ concentration of sap and soil was assessed using a Cardy $\mathrm{NO}_{3}-$ meter, the SPAD chlorophyll meter was used to assess overall tissue $\mathrm{N}$ status, and tissue and soil samples were sent for both $\mathrm{NO}_{3}-\mathrm{N}$ and total $\mathrm{N}$ analysis. Sap for the Cardy meter $\mathrm{NO}_{3}-\mathrm{N}$ readings was taken from the midrib of a recently mature cabbage leaf at the cupping, early heading, and mature growth stages; three to five petioles of recently mature carrot leaves at the early, mid-season, and late growth stages; and onion roots at the 5-leaf, early bulbing, and mature growth stages. Two Cardy readings per replicate were taken in 2000 and this was doubled in 2001.

When plants were at the same growth stages selected for the Cardy sap analysis, SPAD chlorophyll meter readings were taken from 5 and 10 mature leaves per replicate in 2000 and 2001, respectively. Tissue samples for laboratory analysis were also collected from recently mature wrapper leaves in cabbage, petioles in carrots, and leaf blades in onions. Eight to ten soil cores, $20 \mathrm{~cm}$ deep, were collected from each replicate, mixed and separated for Cardy meter and laboratory soil testing. Tissue samples were dried $\left(70^{\circ} \mathrm{C}\right.$ for $\left.48 \mathrm{hrs}\right)$ and soil samples were frozen and sent to $\mathrm{A} \& \mathrm{~L}$ Laboratories East, Inc. (London, Ontario, Canada) in 2000 and University of Guelph Soil and Nutrient Laboratory (Guelph, Ontario, Canada) in 2001.

For Cardy $\mathrm{NO}_{3}-\mathrm{N}$ analysis of mineral soil, $\mathrm{NO}_{3}{ }^{-}$was extracted using one part potassium nitrate/aluminum sulphate extractant to one part dried soil, stirred for two minutes, 
filtered, and tested (procedures provided by Spectrum Technologies). For organic soil $\mathrm{NO}_{3}{ }^{-} \mathrm{N}$ analysis in $2000, \mathrm{NO}_{3}{ }^{-}$was extracted using 2:1 distilled water to moist soil, stirred, let stand for 10 minutes, filtered, and tested. In 2001, organic soil was tested using the mineral soil procedure described above, but using a 2:1 extractant to soil ratio due to excessive absorption of extractant into the dried organic soil. To adjust for the 20 ppm $\mathrm{NO}_{3}-\mathrm{N}$ concentration of the extractant, $20 \mathrm{ppm}$ was subtracted from all readings, and organic soil readings in 2001 were then doubled to account for the extra dilution in this procedure.

Meter readings were compared with the results of laboratory tissue and soil analyses using linear correlation analysis. Regression analysis was performed on the effect of $\mathrm{N}$ rate on total yield in each plot. Mean separation of yields was done by Fisher's Protected LSD Test. Data were analyzed using the GLM, Univariate, and Corr procedures of SAS version 8.0 (SAS Institute, Cary NC) and the linear models section of Statistix V.4.1. A type I error rate of 0.05 was set for all statistical tests.

\section{Results}

\section{Cabbage}

SPAD chlorophyll meter readings in cabbage were correlated with tissue total $\mathrm{N}$ concentrations determined by laboratory analysis at the heading stage in 2000 , and all growth stages in 2001 with double the number of readings per replicate (Table 1).

There was no relationship between the Cardy $\mathrm{NO}_{3}{ }^{-}$meter results for sap analysis on cabbage and laboratory tissue $\mathrm{NO}_{3}-\mathrm{N}$ results at the cupping stage in both years and the heading stage in 2000, but in all other cases Cardy sap readings were correlated with laboratory results (Table 1). The correlation was strongest in 2001, probably as a result of doubling the number of readings.

There was a significant quadratic relationship between total yield and $\mathrm{N}$ application rate in 2000, but no effect of $\mathrm{N}$ application rate on yield was detected in 2001 (Table 2).

\section{Onions}

There was a significant linear correlation between SPAD chlorophyll meter readings and laboratory tissue total $\mathrm{N}$ results in only the 5 -leaf and mature stages on mineral soil in 
2000 , and a correlation between SPAD readings and laboratory tissue $\mathrm{NO}_{3}-\mathrm{N}$ results in the 5-leaf stage in all plots except on organic soil in 2001 (Table 3).

Cardy meter sap $\mathrm{NO}_{3}-\mathrm{N}$ readings on onions were correlated with laboratory tissue $\mathrm{NO}_{3}{ }^{-}$ $\mathrm{N}$ results in all sampling dates except the third sampling date in 2000 on mineral soil (Table 3). On organic soil, a significant correlation was found only in the first two sampling dates in 2000 (Table 3).

There were no significant effects of $\mathrm{N}$ application rate on total yield of onions in either year or location (Table 2).

\section{Carrots}

SPAD chlorophyll meter readings on carrots were correlated with total tissue $\mathrm{N}$ results from laboratory analysis at the second and third sampling dates on mineral soil in 2000 (Tables 4). SPAD readings were also correlated with tissue $\mathrm{NO}_{3}-\mathrm{N}$ concentrations as determined by the laboratory in several instances on mineral soil (Table 4). There were no relationships between SPAD readings and total tissue $\mathrm{N}$ or $\mathrm{NO}_{3}{ }^{-} \mathrm{N}$ concentrations on organic soil in either year (Table 4).

Cardy sap $\mathrm{NO}_{3}-\mathrm{N}$ readings showed a correlation with laboratory tissue $\mathrm{NO}_{3}-\mathrm{N}$ concentrations in most sampling dates in both locations and years (Tables 4). The relationship was stronger early and mid-season than at maturity.

There were no relationships between $\mathrm{N}$ application rate and total yield in any carrot plot (Table 2).

\section{Soil Testing}

In all crops on mineral soil, there was a high positive correlation between the Cardy $\mathrm{NO}_{3}{ }^{-}$meter readings for soil analysis and laboratory soil $\mathrm{NO}_{3}-\mathrm{N}$ analysis results in both years (Table 5). The relationship was much stronger in cabbage in 2001 than in 2000, probably due to a higher range of soil $\mathrm{N}$ concentrations in the 2001 cabbage trial.

On organic soil, Cardy meter readings were not correlated with laboratory results in 2000 , except in carrots at the first sampling date. However, readings were highly correlated with laboratory soil $\mathrm{NO}_{3}-\mathrm{N}$ results in 2001 when the procedure was changed 
from a soilless media analysis to a modified mineral soil analysis (Table 5). Cardy readings underestimated soil $\mathrm{NO}_{3}-\mathrm{N}$ concentrations on organic soil in both years.

\section{Meter use}

Average values of SPAD, Cardy, and laboratory tests are summarized (Table 6). On cabbage, the SPAD meter was generally easy to use. However, it was difficult to avoid leaf veins with the meter, and leaf veins could alter readings significantly. Altered readings were noticeable and could be easily redone. On onions, it was difficult to attain readings in bright conditions due to light transmittance through the interior of the tubular leaf. Sap from the onion leaves gradually built up on the sensing areas necessitating frequent cleaning. In addition, readings of older leaves were much higher than readings of younger leaves. On carrots, due to the finely dissected leaves, it was difficult to place the sensing area properly over the leaf. Consequently, SPAD analysis on carrots was more time consuming and less accurate than analysis of onions or cabbage.

The Cardy meter was relatively easy to use for $\mathrm{NO}_{3}-\mathrm{N}$ analysis of cabbage midrib sap, but more time consuming than SPAD chlorophyll analysis. On onions, since sap from roots had to be sampled, sap extraction was more difficult than in the other crops. Roots had to be washed, dried, and carefully pressed to attain sufficient sap for the meter, and this doubled the time required for readings as compared to cabbage and carrot sap analysis. The sap test was easy to perform on carrots compared with cabbage and onions. However, a build-up of residue was evident on the meter after numerous carrot readings, which may reduce the lifespan of the replaceable sensor. Although time consuming for soil analysis, the Cardy meter soil test was easy to perform.

\section{Discussion}

The success of $\mathrm{N}$ analysis with the SPAD chlorophyll meter was highly dependant on the crop tested. SPAD meter readings showed a correlation with laboratory analysis on cabbage in both years, but on onions and carrots the meter was of limited usefulness. The reasons for these differences appear to be twofold. First, since the meter was designed for flat cereal leaves, the cabbage leaf may be more appropriate for SPAD analysis than either onions or carrots. Secondly, there was more variability in yield and leaf colour among treatments in the cabbage than either onions or carrots, which may 
have provided a greater range of chlorophyll readings for comparison with lab results. Furthermore, a lack of yield differences in onions and carrots suggests that these plants had sufficient $\mathrm{N}$ concentrations, and chlorophyll levels plateau in an $\mathrm{N}$ sufficiency (Schepers et al., 1992), limiting the success of correlation analysis. Further research on all three crops is warranted because of the speed of the procedure over other techniques. A suitable analysis of cabbage, involving 40 readings per treatment in this study, required only two minutes to perform. On onions and carrots more time would be required due to the shape of the leaves.

The Cardy NO3 - meter provided a good indication of actual soil and sap $\mathrm{NO}_{3}-\mathrm{N}$ concentrations in all three crops, but readings were more time consuming than those with a SPAD meter. Cardy meter readings were highly correlated with lab results in most cases. Doubling the number of readings per treatment for sap analysis in 2001 resulted in a much stronger relationship with lab results. Consequently, 10-20 readings were required for an accurate determination of sap $\mathrm{NO}_{3}-\mathrm{N}$ concentrations. For onion root sap analysis, the time required was even longer. Proper soil analysis with the Cardy meter was also time consuming, even though only four or five readings per site were required for accurate analysis of soil.

The Minolta SPAD-502 chlorophyll meter appeared to be a useful tool for cabbage and there is some potential for onion $\mathrm{N}$ analysis. On carrots, the SPAD meter was not as successful, which was due to the shape of the leaves. The Cardy $\mathrm{NO}_{3}^{-}$meter has potential for use on all three crops because it can be used for both soil and sap analysis, and readings closely matched lab tissue and soil analysis results in most cases. With appropriate standards for tissue and soil $\mathrm{NO}_{3}-\mathrm{N}$ concentrations, the Cardy meter could be a relatively inexpensive and rapid method for $\mathrm{N}$ analysis. However, users must be willing to spend some time in the analysis process.

\section{Acknowledgements}

We thank Kevin Vander Kooi, Shawn Janse, and Cathy Bakker for their technical assistance. Funding was provided by the Canada-Ontario Research and Development Fund of the Agricultural Adaptation Council through the support of the Ontario Fruit and Vegetable Grower's Association. 


\section{Literature cited}

Blackmer, T.M. and Schepers, J.S. 1995. Use of a chlorophyll meter to monitor nitrogen status and schedule fertigation for corn. J. Prod. Agri. 8:56-60.

Delgado, J.A. and Follett, R.F. 1998. Sap test to determine nitrate-nitrogen concentrations in aboveground biomass of winter cover crops. Commun. Soil Sci. Plant Anal. 29:545-559.

Dwyer, L.M., Tollenaar, M. and Houwing, L. 1991. A nondestructive method to monitor leaf greenness in corn. Can. J. Plant Sci. 71:505-509.

Follett, R.H., Follett, R.F., and Halvorson, A.D. 1992. Use of a chlorophyll meter to evaluate the nitrogen status of dryland winter wheat. Commun. Soil Sci. Plant Anal. 23:687-697.

Gardner, B.R. and Roth, R.L. 1989. Midrib nitrate concentration as a means for determining nitrogen needs of broccoli. J. Plant Nutr. 12:111-125.

Hartz, T.K., Smith, R.F., LeStrange, M. and Schulbach, K.F. 1993. On-farm monitoring of soil and crop nitrogen status by nitrate-selective electrode. Commun. Soil Sci. Plant Anal. 24:2607-2615.

Kubota, A., Thompson, T.L., Doerge, T.A. and Godin, R.E. 1996. A petiole sap nitrate test for cauliflower. HortScience 31:934-937.

Kubota, A., Thompson, T.L., Doerge, T.A., and Godin, R.E. 1997. A petiole sap nitrate test for broccoli. J. Plant Nutr. 20:669-682.

Ontario Ministry of Agriculture, Food, and Rural Affairs. 2000. Vegetable production recommendations. Publ. 363. Queen's Printer for Ontario, Toronto.

Piekielek, W.P. and Fox, R.H. 1992. Use of a chlorophyll meter to predict sidedress nitrogen requirements for maize. Agron. J. 84:59-65.

Reeves, D.W., Mask, P.L., Wood, C.W. and Delaney, D.P. 1993. Determination of wheat nitrogen status with a hand-held chlorophyll meter: influence of management practices. J. Plant Nutr. 16:781-796.

Schepers, J.S., Francis, D.D., Vigil, M. and Below, F.E. 1992. Comparison of corn leaf nitrogen concentration and chlorophyll meter readings. Commun. Soil Sci. Plant Anal. 23:2173-2187.

Turner, F.T. and Jund, M.F. 1991. Chlorophyll meter to predict nitrogen topdress requirement for semidwarf rice. Agron. J. 83:926-928.

Warncke, D.D. 1996. Soil and plant tissue testing for nitrogen management in carrots. Commun. Soil Sci. Plant Anal. 27:597-605.

Westcott, M.P., Rosen, C.J. and Wraith, J.M. 1993. Direct measurement of petiole sap nitrate in potato to determine crop nitrogen status. J. Plant Nutr. 16:515-521. 
Wood, C.W., Reeves, D.W., Duffield, R.R. and Edmisten, K.L. 1992. Field chlorophyll measurements for evaluation of corn nitrogen status. J. Plant Nutr. 15:487-500.

\section{Tables}

Table 1. Linear correlation coefficients ( $r$ ) for the comparison of Cardy nitrate meter (Cardy) and SPAD chlorophyll meter readings (SPAD) to laboratory analysis for cabbage grown on mineral soil in 2000 and 2001.

\begin{tabular}{|c|c|c|c|c|c|c|}
\hline 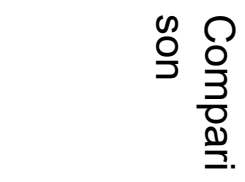 & 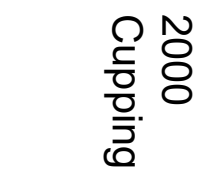 & 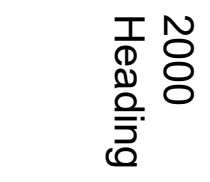 & $\begin{array}{l}\underset{1}{\mathbb{D}} \\
\frac{\mathrm{E}}{\bar{D}}\end{array}$ & 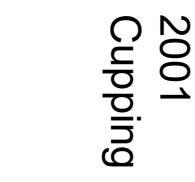 & 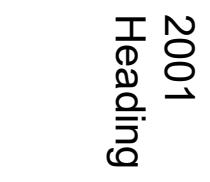 & 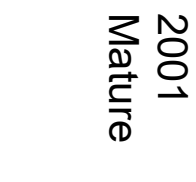 \\
\hline $\begin{array}{l}\text { SPAD/tissue } \\
\text { total N }\end{array}$ & 0.38 & $0.53^{*}$ & 0.15 & $0.73^{* * *}$ & $0.80^{* * *}$ & $0.86^{* * *}$ \\
\hline $\begin{array}{l}\text { SPAD/tissue } \\
\mathrm{NO}_{3}-\mathrm{N}\end{array}$ & 0.47 & 0.47 & -0.12 & $0.60^{* *}$ & $0.78^{* * *}$ & $0.76^{* *}$ \\
\hline $\begin{array}{l}\text { Cardy } \\
\text { sap/tissue } \\
\mathrm{NO}_{3}{ }^{-} \mathrm{N}\end{array}$ & -0.02 & 0.46 & $0.52^{*}$ & 0.32 & $0.83^{* * *}$ & $0.89^{* * *}$ \\
\hline
\end{tabular}

${ }^{*},{ }^{* *},{ }^{* * *}$ Linear correlation significant at PP $0.05,0.01$, and 0.001 respectively.

Table 2. Total yields of cabbage, carrots, and onions as affected by $\mathrm{N}$ application rate on mineral and organic soils in Ontario in 2000 and 2001.

\begin{tabular}{|c|c|c|c|c|c|c|c|c|c|c|}
\hline & $\begin{array}{l}\text { Total } \\
\text { Yield } \\
(\mathrm{t} / \mathrm{ha})^{z}\end{array}$ & $\begin{array}{l}\text { Total } \\
\text { Yield } \\
(\mathrm{t} / \mathrm{ha})^{\mathrm{z}} \\
\end{array}$ & $\begin{array}{l}\text { Total } \\
\text { Yield } \\
(\mathrm{t} / \mathrm{ha})^{\mathrm{z}}\end{array}$ & $\begin{array}{l}\text { Total } \\
\text { Yield } \\
(\mathrm{t} / \mathrm{ha})^{\mathrm{z}} \\
\end{array}$ & $\begin{array}{l}\text { Total } \\
\text { Yield } \\
(\mathrm{t} / \mathrm{ha})^{\mathrm{z}}\end{array}$ & $\begin{array}{l}\text { Total } \\
\text { Yield } \\
(\mathrm{t} / \mathrm{ha})^{\mathrm{z}} \\
\end{array}$ & $\begin{array}{l}\text { Total } \\
\text { Yield } \\
(\mathrm{t} / \mathrm{ha})^{\mathrm{z}}\end{array}$ & $\begin{array}{l}\text { Total } \\
\text { Yield } \\
(\mathrm{t} / \mathrm{ha})^{\mathrm{z}}\end{array}$ & $\begin{array}{l}\text { Total } \\
\text { Yield } \\
(\mathrm{t} / \mathrm{ha})^{\mathrm{z}}\end{array}$ & $\begin{array}{l}\text { Total } \\
\text { Yield } \\
(\mathrm{t} / \mathrm{ha})^{\mathrm{z}}\end{array}$ \\
\hline 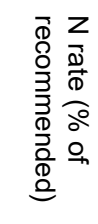 & 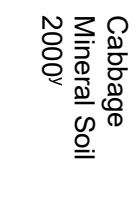 & 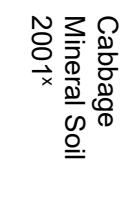 & 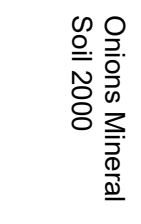 & 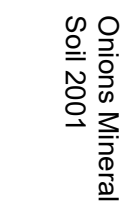 & 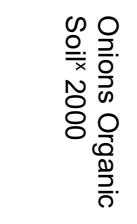 & 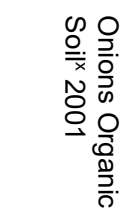 & 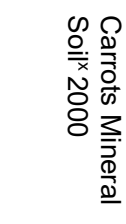 & 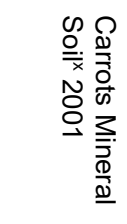 & 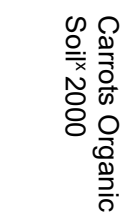 & 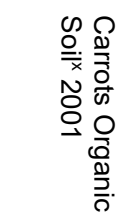 \\
\hline 0 & $36.3 a$ & 59.2 & 9.4 & 18.2 & 40.9 & 98.0 & 64.1 & 47.4 & 25.8 & 95.3 \\
\hline 50 & $63.6 b$ & 63.8 & -- & -- & -- & -- & 79.8 & 49.7 & 22.8 & 92.8 \\
\hline 100 & $62.7 b$ & 57.9 & 7.4 & 16.9 & 42.0 & 80.5 & 73.6 & 40.6 & 22.7 & 89.1 \\
\hline 150 & $69.3 b$ & 70.5 & -- & -- & -- & -- & 76.7 & 48.4 & 20.2 & 90.1 \\
\hline 200 & $69.6 b$ & 58.1 & 9.7 & 16.4 & 41.4 & 92.8 & 74.6 & 51.6 & 19.2 & 87.1 \\
\hline LSD & 12.1 & NS & NS & NS & NS & NS & NS & NS & NS & NS \\
\hline
\end{tabular}

z Numbers in a column followed by the same letter are not significantly difference at $P=0.05$, Fisher's Protected LSD Test; NS= not significant.

${ }^{y}$ Regression: $P=0.0003, R^{2}=0.61$, Equation: (Total yield in $t /$ ha $)=39.16+0.4114($ Nrate $)-$ $0.00133(\text { Nrate) })^{2}$.

$\times$ Linear and quadratic regression analysis not significant at $P=0.05$. 
Table 3. Linear correlation coefficients ( $r$ ) for the comparison of Cardy nitrate meter (Cardy) and SPAD chlorophyll meter readings (SPAD) to laboratory analysis for onions grown on mineral and organic soil in 2000 and 2001.

\begin{tabular}{|c|c|c|c|c|c|c|}
\hline 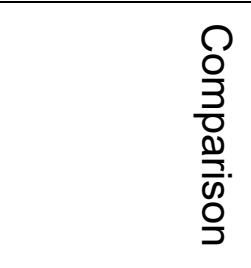 & 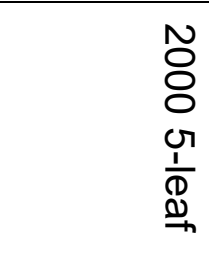 & 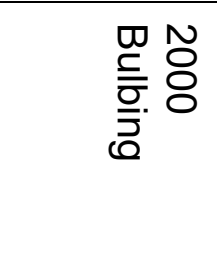 & 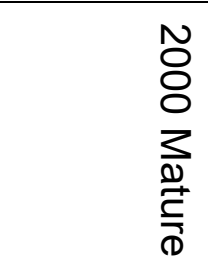 & 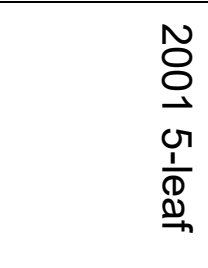 & 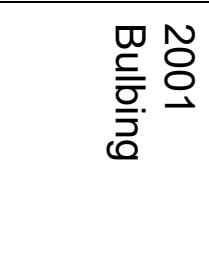 & 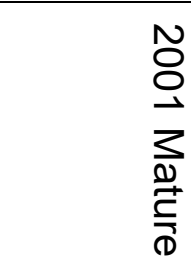 \\
\hline \multicolumn{7}{|l|}{ Mineral Soil } \\
\hline $\begin{array}{l}\text { SPAD/tissue } \\
\text { total N }\end{array}$ & $0.95^{* * *}$ & 0.50 & $0.72^{*}$ & 0.56 & 0.27 & 0.55 \\
\hline $\begin{array}{l}\text { SPAD/tissue } \\
\mathrm{NO}_{3}-\mathrm{N}\end{array}$ & $0.87^{* *}$ & 0.43 & 0.62 & $0.74^{* *}$ & 0.05 & 0.21 \\
\hline $\begin{array}{l}\text { Cardy } \\
\text { sap/tissue } \\
\mathrm{NO}_{3}-\mathrm{N}\end{array}$ & $0.87^{* *}$ & $0.93^{* * *}$ & 0.37 & $0.88^{* * *}$ & $0.67^{*}$ & $0.75^{*}$ \\
\hline \multicolumn{7}{|l|}{$\begin{array}{l}\text { Organic } \\
\text { Soil }\end{array}$} \\
\hline $\begin{array}{l}\text { SPAD/tissue } \\
\text { total N }\end{array}$ & 0.44 & -0.52 & 0.29 & 0.04 & 0.19 & -0.22 \\
\hline $\begin{array}{l}\text { SPAD/tissue } \\
\mathrm{NO}_{3}-\mathrm{N}\end{array}$ & $0.72^{*}$ & -0.65 & 0.08 & -0.03 & 0.46 & -0.03 \\
\hline $\begin{array}{l}\text { Cardy } \\
\text { sap/tissue } \\
\mathrm{NO}_{3}-\mathrm{N}\end{array}$ & $0.79^{*}$ & $0.88^{* *}$ & 0.15 & 0.54 & 0.65 & -0.11 \\
\hline
\end{tabular}

${ }^{*},{ }^{* *},{ }^{* * *}$ Linear correlation significant at PP $0.05,0.01$, and 0.001 respectively.

Table 4. Linear correlation coefficients ( $r$ ) for the comparison of Cardy nitrate meter (Cardy) and SPAD chlorophyll meter readings (SPAD) to laboratory analysis for carrots grown on mineral and organic soil in 2000 and 2001.

\begin{tabular}{|c|c|c|c|c|c|c|}
\hline $\begin{array}{l}0 \\
\frac{0}{3} \\
\frac{3}{0} \\
\frac{0}{3} \\
\frac{1}{0} \\
\frac{0}{1}\end{array}$ & 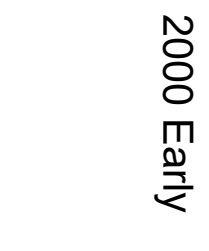 & $\begin{array}{l}\text { 응 } \\
\text { ᄋ } \\
\text { 즌 }\end{array}$ & $\begin{array}{l}\text { No } \\
8 \\
\varnothing \\
\Gamma \\
\stackrel{0}{\mathbb{D}}\end{array}$ & 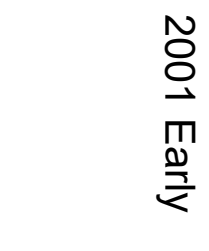 & 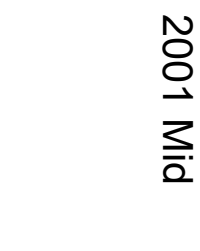 & $\begin{array}{l}\text { 응 } \\
\stackrel{+}{0} \\
\stackrel{0}{0}\end{array}$ \\
\hline \multicolumn{7}{|l|}{ Mineral Soil } \\
\hline $\begin{array}{l}\text { SPAD/tissue } \\
\text { total N }\end{array}$ & 0.35 & $0.58^{*}$ & $0.65^{* *}$ & 0.40 & 0.29 & 0.41 \\
\hline $\begin{array}{l}\text { SPAD/tissue } \\
\mathrm{NO}_{3}-\mathrm{N}\end{array}$ & 0.26 & $0.56^{*}$ & $0.57^{*}$ & $0.50^{*}$ & 0.32 & $0.52^{*}$ \\
\hline $\begin{array}{l}\text { Cardy } \\
\text { sap/tissue } \\
\mathrm{NO}_{3}-\mathrm{N}\end{array}$ & $0.79^{\star * \star}$ & $0.78^{* * *}$ & 0.38 & $0.77^{* *}$ & $0.96^{* * *}$ & $0.71^{* *}$ \\
\hline
\end{tabular}




\begin{tabular}{|c|c|c|c|c|c|c|}
\hline $\begin{array}{l}\Omega \\
\frac{0}{3} \\
\frac{3}{0} \\
\frac{9}{\bar{y}} \\
\frac{0}{0}\end{array}$ & $\begin{array}{l}\text { 응 } \\
8 \\
\text { m } \\
\stackrel{\otimes}{<}\end{array}$ & $\begin{array}{l}\text { 응 } \\
\text { ᄋ } \\
\text { 즌 }\end{array}$ & $\begin{array}{l}\text { No } \\
\varnothing \\
0 \\
\Gamma \\
\stackrel{0}{\mathbb{D}}\end{array}$ & 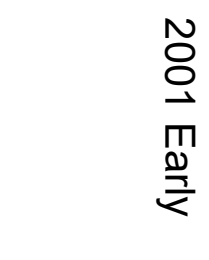 & 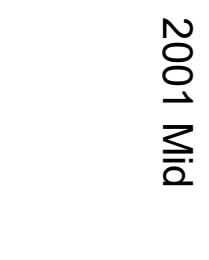 & $\begin{array}{l}\stackrel{N}{O} \\
\stackrel{0}{+} \\
\stackrel{D}{\mathbb{D}}\end{array}$ \\
\hline \multicolumn{7}{|l|}{$\begin{array}{l}\text { Organic } \\
\text { Soil }\end{array}$} \\
\hline $\begin{array}{l}\text { SPAD/tissue } \\
\text { total N }\end{array}$ & -0.02 & -0.26 & -- & -0.18 & 0.20 & -0.33 \\
\hline $\begin{array}{l}\text { SPAD/tissue } \\
\mathrm{NO}_{3}-\mathrm{N}\end{array}$ & 0.02 & -0.18 & -- & 0.11 & 0.14 & -0.38 \\
\hline $\begin{array}{l}\text { Cardy } \\
\text { sap/tissue } \\
\mathrm{NO}_{3}-\mathrm{N}\end{array}$ & $0.83^{* * *}$ & $0.74^{* *}$ & -- & 0.26 & $0.80^{\star \star *}$ & 0.50 \\
\hline
\end{tabular}

${ }^{*},{ }^{* *},{ }^{* * *}$ Linear correlation significant at PP $0.05,0.01$, and 0.001 respectively.

Table 5. Linear correlation coefficients ( $r$ ) for the comparison of Cardy nitrate meter (Cardy) soil nitrate readings to laboratory analysis for cabbage, carrot, and onion crops grown on organic and mineral soil in 2000 and 2001.

\begin{tabular}{|c|c|c|c|c|c|c|}
\hline $\begin{array}{l}0 \\
\frac{0}{3} \\
\frac{3}{0} \\
\frac{9}{3} \\
\frac{1}{0} \\
\frac{0}{2}\end{array}$ & $\begin{array}{l}\text { 응 } \\
8 \\
\text { m } \\
\stackrel{\otimes}{2}\end{array}$ & $\begin{array}{l}\text { 응 } \\
\text { ᄋ } \\
\text { ㅈ. }\end{array}$ & $\begin{array}{l}\text { No } \\
\varnothing \\
0 \\
\stackrel{0}{0} \\
\stackrel{0}{\mathbb{D}}\end{array}$ & 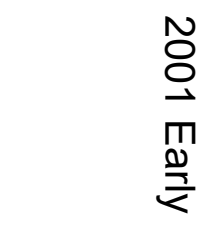 & $\begin{array}{l}\text { No } \\
\text { O } \\
\text { z. } \\
\text { a. }\end{array}$ & $\begin{array}{l}\text { 응 } \\
\stackrel{0}{+} \\
\stackrel{0}{0}\end{array}$ \\
\hline \multicolumn{7}{|l|}{ Mineral Soil } \\
\hline Cabbage & $0.50^{*}$ & $0.48^{*}$ & $0.50^{*}$ & $0.76^{\star \star \star}$ & $0.91^{* \star *}$ & $0.97^{\star \star \star}$ \\
\hline Onions & $0.97^{* * *}$ & $0.98^{* * *}$ & $0.96^{* * *}$ & $0.91^{* * *}$ & $0.79 z^{\star}$ & $0.98^{* * *}$ \\
\hline Carrots & $0.98^{* * *}$ & $0.94^{\star * *}$ & $0.53^{*}$ & $0.94^{* * *}$ & $0.89^{\star \star *}$ & $0.59^{*}$ \\
\hline \multicolumn{7}{|l|}{$\begin{array}{l}\text { Organic } \\
\text { Soil }\end{array}$} \\
\hline Onions & 0.57 & 0.07 & -0.49 & $0.93^{* * *}$ & $0.86^{* *}$ & $0.97^{* * *}$ \\
\hline Carrots & $0.78^{\star \star *}$ & 0.56 & & $0.61^{* *}$ & $0.70^{* *}$ & $0.92^{* * *}$ \\
\hline
\end{tabular}

${ }^{z}$ One outlier removed for analysis.

${ }_{*}^{* * *},{ }^{* * *}$ Linear correlation significant at PP $0.05,0.01$, and 0.001 respectively.

Table 6. Yearly mean SPAD (+/- SE) chlorophyll readings, Cardy sap and soil nitrate readings, and laboratory tissue and soil test values for cabbage (Cab.), onions (Oni.), and carrots (Car.) grown on mineral (Min.) and organic (Org.) soil in 2000 and 2001. 


\begin{tabular}{|c|c|c|c|c|c|c|}
\hline$\frac{\rho}{0}$ & 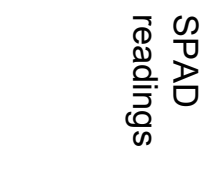 & 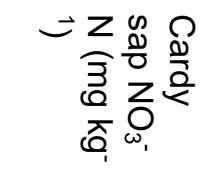 & 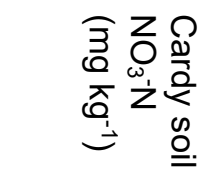 & 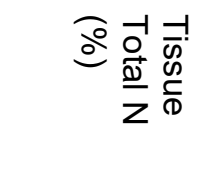 & 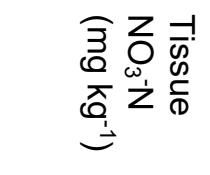 & 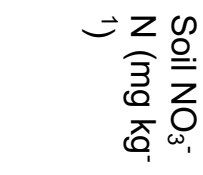 \\
\hline \multicolumn{7}{|l|}{2000} \\
\hline Min. Cab. & $63(1.3)$ & $1300(118)$ & $10(0.6)$ & $3.1(0.08)$ & $8590(1450)$ & $7(0.5)$ \\
\hline Min. Oni. & $62(1.1)$ & $460(86)$ & 59 (12.1) & $3.2(0.08)$ & $920(188)$ & $46(8.3)$ \\
\hline Min. Car. & $39(0.6)$ & $740(67)$ & $22(2.6)$ & $1.3(0.10)$ & $3710(564)$ & $20(2.2)$ \\
\hline Org. Oni. & $53(0.7)$ & $340(33)$ & $39(1.7)$ & $3.5(0.08)$ & $1220(166)$ & $76(9.1)$ \\
\hline Org. Car. & $34(0.5)$ & $310(32)$ & $27(1.0)$ & $1.6(0.06)$ & $2720(375)$ & $236(16)$ \\
\hline \multicolumn{7}{|l|}{2001} \\
\hline Min. Cab. & $69(1.2)$ & $1880(102)$ & $48(5.1)$ & $3.9(0.10)$ & $5050(360)$ & $38(4.1)$ \\
\hline Min. Oni. & $67(0.5)$ & $540(49)$ & $49(5.4)$ & $3.6(0.11)$ & $1950(290)$ & $37(4.4)$ \\
\hline Min. Car. & $40(0.4)$ & $250(32)$ & $15(2.9)$ & $1.0(0.03)$ & $810(126)$ & $16(2.3)$ \\
\hline Org. Oni. & $58(0.5)$ & $640(67)$ & $139(9.3)$ & $3.7(0.13)$ & $2710(414)$ & $286(24)$ \\
\hline Org. Car. & $42(0.3)$ & $1150(94)$ & $178(8.3)$ & $1.7(0.07)$ & 6240 (582) & $386(18)$ \\
\hline
\end{tabular}

